\title{
Fund Shareholding and Enterprise Innovation-Based on the Research of Chinese A-Share Listed Companies
}

\author{
Hanyu Li \\ School of Economics, Jinan University, Guangzhou, China \\ Email: hanyu1231129@126.com
}

How to cite this paper: Li, H.Y. (2019) Fund Shareholding and Enterprise Innovation-Based on the Research of Chinese A-Share Listed Companies. American Journal of Industrial and Business Management, 9, 914-929.

https://doi.org/10.4236/ajibm.2019.94063

Received: March 20, 2019

Accepted: April 19, 2019

Published: April 22, 2019

Copyright () 2019 by author(s) and Scientific Research Publishing Inc. This work is licensed under the Creative Commons Attribution International License (CC BY 4.0).

http://creativecommons.org/licenses/by/4.0/

\begin{abstract}
This paper takes China's A-share listed companies in 2006-2016 as a sample, and divides fund investors into long-term funds and short-term funds according to the average position time. It empirically analyzes the impact of funds of different transaction nature on enterprise R\&D investment. The research findings in this paper are as follows: Different from the "short-sighted theory" in previous studies, short-term fund does not inhibit the investment in research and development, and long-term fund ownership can significantly promote the innovation investment of the company. In high-tech enterprises, this kind of promotion effect is inhibited, but the inhibition effect is not obvious.
\end{abstract}

\section{Keywords}

Fund Holdings, R\&D Expenditures, Long-Term Funds, Short-Term Funds, Average Holding Time

\section{Introduction}

Institutional investors have always been an important player in the stock market. In recent years, they have gradually developed into an investor group that is composed of public funds, private equity funds, insurance social security funds, pension funds, QFII and other institutions that are different from individual investors. Since the establishment of China's stock market, institutional investors have entered a stage of rapid development, and the stock market value has continued to grow. In 2016, Chinese institutional investors held a stock market value of $16.3 \%$ of the total stock market. Among them, the development of equity funds is also growing rapidly. From 2005, there was only one stock fund. In 
2018, more than 360 companies were active in the A-share market.

Innovation is the decisive force for a country to achieve sustainable economic development [1]. At present, China is at a critical stage of economic transformation, and innovative development is one of the major national development strategies [2]. This year's government work report puts forward that we should persist in innovation to lead development, cultivate and strengthen new drivers of growth, reform and innovate the mechanism of R\&D and industrial application of science and technology, vigorously cultivate professionalism, and promote the continuous transformation of old and new drivers of growth.

$\mathrm{R} \& \mathrm{D}$ input is the basic guarantee for enterprises to develop intangible assets, implement differentiation strategy and product innovation. Through continuous $R \& D$ investment, enterprises can form intangible assets such as patents and increase the value of various elements in their asset portfolios. Enterprises usually improve their core competitiveness through innovation, which usually requires constant trial and error, and suffers from a long period of input and output that is not proportional. Compared with general companies, listed companies have more advantages in innovative financing. However, public ownership also makes the company's management face performance pressure, thus reducing the investment in innovation and turning to production activities that are easier to obtain short-term benefits. This is also true of institutional investors, particularly fund companies, which are under pressure to regularly present performance statements to fund holders. On the other hand, compared with individual investors, institutional investors have strong financial strength and sufficient human resources to fully collect enterprise information and reduce information asymmetry related to innovation and research and development. Institutional investors sometimes pay more attention to the long-term value of a company and influence innovation activities by participating in corporate governance, prompting management to increase investment in research and development. However, not all institutional investors contributed to technological innovation. Graves \& Waddock (1990) believed that institutional investors could not necessarily enhance corporate governance [3]. On the contrary, institutional investors traded frequently and only focused on short-term profits, which did not play a role in corporate governance. Borochin \& Yang (2017) found that different types of institutional investors play different roles in evaluating enterprise value and participating in the process of corporate governance. They divided institutional investors into focused institutional investors and temporary institutional investors, among which only focused institutional investors can strengthen corporate governance [4]. In fact, Bushee found through research that when the proportion of institutional investors is at a high level, institutional investors can promote the technological innovation of enterprises, but when there are institutional investors with high turnover rate and impulse trading, managers will cut down the R\&D expenditure to cope with the decline in profits [5]. Yan \& Zhang (2009) calculated and distinguished long-term institutional investors from short-term institutional investors based on the liquidity of institutional investors [6]. There- 
fore, based on the research methods of Yan et al., this paper distinguishes long-term institutional investors from short-term institutional investors and examines their different effects on technological innovation of enterprises.

The innovation of this paper: First, whether the average holding position of the fund is greater than one year is used as the basis for dividing the long-term fund and the short-term fund, which is different from the turnover rate used in most of the previous literature; second, this paper The impact of heterogeneous funds on corporate innovation is discussed, and the impact of this impact on Chinese high-tech enterprises and ordinary enterprises is analyzed.

The structure of this paper is organized as follows: Section 2 summarizes the research results of previous related literature. Section 3 elaborates on the theory and makes assumptions. Section 4 is the research design, that is, the preparation before the evidence, mainly including the short-term classification of the fund, model construction, sample selection and data processing. Section 5 is a concrete empirical analysis. Section 6 is the conclusion and recommendations.

\section{Literature Review}

There is little research on the impact of fund ownership on enterprise innovation at home and abroad. Most of the relevant literature focuses on the impact of institutional investors on enterprise innovation. For example, Bushee (1998) found that companies with larger institutional ownership are less likely to cut back on research and development spending to reverse declining earnings. Aghion et al. (2013) have found that institutional ownership has a positive impact on innovation by alleviating managers' professional concerns [7]. Francis \& Smith (2004) found a positive correlation between ownership concentration (including institutions) and R\&D expenditure [8]. Eng \& Shackell (2001) found that institutional investors can promote technological innovation of enterprises [9]. On the impact of short-sightedness on innovation, there are the following studies: Stein $(1988,1989)$ discussed the optimal management decisions of investors' short-sightedness and irrational stock market [10] [11]. Asker et al. (2015) show that short-termism distorts the investment and innovation decisions of American public enterprises [12]. Koh (2007) found that long-term investors can inhibit the earnings management behavior of companies. For companies with motivation and ability to achieve the target profit through accrual profit, short-term opportunist shareholding is positively correlated with earnings management [13]. Acharya \& Xu (2017) found that public listing is beneficial to enterprise innovation in industries that are more dependent on external financing [14]. Hsu et al. (2014) found that the development of the stock market has a positive impact on innovation [15].

In recent years, there have been many researches on the relationship between institutional investors and enterprise innovation in China. Jiang Yanhui (2013) to the information technology industry, manufacturing industry and medicine, biological products R\&D of high and new technology industry listed companies 
such as empirical analysis, the study found that institutional investors holding that there was no significant correlation between corporate $R \& D$, but long-term investor holds and enterprise $\mathrm{R} \& \mathrm{D}$ investment has significant positive correlation, short-term institutional investors holding is negatively related to the enterprise R\&D spending [16]. Hong min et al. (2018) examined the relationship between institutional investors and technological innovation, and found that institutional shareholders promote technological innovation, which is mainly reflected in long-term institutional investors [17]. Ming Yaxin et al. (2018) found that the higher the shareholding ratio of institutional investors, the higher the $\mathrm{R} \& \mathrm{D}$ investment level of the company, and long-term institutional investors are more able to promote the investment in enterprise R\&D, and the promotion effect of institutional investors on enterprise $R \& D$ investment is more obvious in private enterprises and companies with higher growth [18]. Feng Genfu (2017) et al. studied the different effects of heterogeneous institutions on technological innovation of enterprises and found that securities investment funds have a significant negative effect on enterprise innovation, which is more obvious in state-owned enterprises [19]. By studying the impact of accounting conservatism on corporate innovation, Zhong Yuxiang (2017) found that the higher the shareholding ratio of institutional investors, the more significant the inhibitory effect of accounting conservatism on corporate innovation [20]. Bo Xianhui et al. (2009) found through research that institutional investors are beneficial to the improvement of corporate governance, but the active governance role of institutional investors is limited in state-owned holding companies [21].

Different from the previous literature, using Yan's turnover rate method to distinguish long-term institutional investors from short-term institutional investors, this paper uses the wind platform to improve the calculated average fund holding time based on the method of Yan et al. fund. In the past, most of the relevant literature focused on the impact of institutional investors' shareholding on corporate innovation, and rarely discussed the importance of fund holdings. The research in this paper enriches the content of this research field.

\section{Theoretical Analysis and Research Hypotheses}

Long-term institutional investors promote long-term investment in innovation by playing a regulatory role. This positive impact stems from the existence of institutions that have a disciplinary impact on people within the company. Institutional investors can persuade managers, who tend to make smooth decisions, to innovate. Compared with short-term institutional investors and individual investors, long-term institutional investors are better able to tolerate the trade-off between high risks and high returns related to innovation investment, because institutional investors can diversify risks through multiple portfolios, and long-term investors have more choices in the term structure allocation of stocks. Compared with individual investors, long-term rational institutional investors can realize the importance of enterprise $R \& D$ investment to the long-term value of 
the company. In addition, the professional, information and capital advantages of institutional investors can effectively restrict the opportunistic behaviors such as the embezzlement of company funds by the management and increase the resources of enterprises for long-term investment such as R\&D investment. Based on the above analysis, this paper proposes hypothesis $\mathrm{H} 1$.

H1: there is a significant positive correlation between long-term fund ownership and innovation input and output of enterprises.

The existence of institutional investors can lead managers to reduce capital expenditure. R\&D input can improve the innovation ability of enterprises and generate profits, but at the same time, $R \& D$ input can also generate high degree of uncertainty, complexity and cost. The expensing of $\mathrm{R} \& \mathrm{D}$ expenditure is a form of its cost, and the expensing of expenditure will reduce the short-term income of enterprises. Short-term opportunists pay more attention to the short-term earnings of enterprises, so short-term opportunists tend to spend less on R\&D and even hinder the R\&D investment of enterprises. In addition, the portfolio flows of short-term institutional investors represent the "hot money" of short-term profits and pay little attention to the long-term development of enterprises. Short-term strategies often provide immediate returns to shareholders at the expense of long-term investments. If short-term institutional investors prompt managers to prioritize short-term gains over long-term growth, they may generate market pressures that trigger short-term behavior. Ferrera and others argue that the stock market forces managers to choose projects where they can easily communicate with investors, and that managers abandon innovation in favor of existing production models and technologies, which are more intuitive and transparent to investors. All these factors may cause company managers to turn away from the opportunities to pursue innovative growth. Based on the above analysis, this paper proposes hypothesis $\mathrm{H} 2$.

$\mathrm{H} 2$ : there is a significant negative correlation between short-term fund shareholding and innovation input and output of enterprises.

\section{Study Design}

\subsection{Classification of Long-Term Funds and Short-Term Funds}

For the classification of the long-term and short-term institutional investors, generally in accordance with the trading turnover rate (churn rate) of high and low, Bushee (2004) the earliest discovered the institutional investors have the characteristics of different trades, according to the holding stability and the scale of holding two dimension classifying institutions are: 1) "brief" institutions, its portfolio showed high turnover rate and has small equity; 2) "full-time" institutions with stable and large equity stakes in individual enterprises; 3) "quasi-index" institutions, infrequently traded and small stakes (similar to index strategies). According to Gaspar (2005) [22], the difference between long-term and short-term institutional investors lies in different trading frequencies. $\mathrm{He}$ used the "churn rate" to indicate that each institutional investor measures the frequency at which he rotates his position in all stocks in his portfolio. Yan et al. 
(2009), on the basis of Gaspar method, calculated the turnover rate of institutional investors in the current period by replacing the sum of the total stock assets with the smaller value of the total stock assets in the current period. Such calculation can reduce the impact of cash flow owned by institutional investors on asset portfolio. Chinese scholars Liu Jingjun et al. (2012) [23], Jiang Yanhui et al. (2013), Hong Min et al. (2018), Liu Wei et al. (2018) [2] also refer to the method of Yan et al., and use the turnover rate of institutional investors to divide long-term institutional investors and short-term institutional investors. And wind platform proposed according to this method, the average time of defined institutional investors for interval length divided by the current turnover rate, but the turnover rate of slightly different calculation methods, such as Yan, is to use the larger value of current buying and selling assets divided by the average range in stock market value to calculate the current and other calculation steps are consistent with the methods, such as Yan. Based on the extensive application of Yan and other methods and the availability of data, this paper divides the long-term and short-term institutional investors by the average holding time. The specific calculation method is as follows:

First, calculate the cumulative total stock assets bought and sold by each stock fund over the course of each half-year period. For fund $K$, the calculation formula of the cumulative total stock assets bought and sold in each half year is:

$$
\begin{gathered}
\text { CR_buy }_{k, i}=\sum_{i=1}^{N}\left|\left(S_{k, i, t}-S_{k, i, t-1}\right) P_{i, t}\right|\left(S_{k, i, t}>S_{k, i, t-1}\right) \\
\text { CR_sell }{ }_{k, i}=\sum_{i=1}^{N}\left|\left(S_{k, i, t}-S_{k, i, t-1}\right) P_{i, t}\right|\left(S_{k, i, t}<S_{k, i, t-1}\right)
\end{gathered}
$$

where, $P_{i, t}$ and $P_{i, t-1}$ are the stock prices of stock $i$ in period $\mathrm{t}$ and period $t-1 ; S_{k, i, t}$ and $S_{k, i, t-1}$ are the number of stock I held by stock fund $K$ in period $t$ and period $t$ - 1; CR_buy ${ }_{k, i}$ and CR_sell ${ }_{k, i}$ are the total stock assets bought or sold by fund $K$ in period $t$; then the turnover rate of fund $K$ in period $t$ is defined as:

$$
\mathrm{CR}_{k, t}=\frac{\max \left(\mathrm{CR} \_ \text {buy }_{k, t}, \mathrm{CR} \_ \text {sell }_{k, t}\right)}{\mathrm{AVG}\left(S_{k, i, t} P_{k, i, t}\right)}
$$

where AVG_ $\left(S_{k, i, t} P_{k, i, t}\right)$ is the average stock market value of $K$ fund in the four quarters of year $t$, then the average turnover rate of $K$ fund in the current and the past four periods is:

$$
\text { AVG_PT }=\frac{\mathrm{IP}}{\mathrm{CR}_{k, t}}
$$

As the data in this paper are all annual data, IP $=1$ for the interval year.

In this paper, the average holding time of funds greater than and equal to 1 year is set as long-term investors, or as short-term investors. Then calculate the proportion of each stock owned by medium-and long-term institutional investors and short-term institutional investors.

From 2006 to 2015, the detailed data of wind's holdings classified as stock funds and hybrid funds were selected, and the funds with no establishment time 
after 2015 and no average holding time within the range were excluded. Finally, 1474 funds were obtained.

\subsection{Model Design}

To test hypothesis 1 , that is, long-term fund shareholding has a significant positive impact on enterprise $\mathrm{R} \& \mathrm{D}$ expenditure, this paper constructs the model (1):

$$
\operatorname{rdint}_{i, t}=\alpha_{0}+\alpha_{1} \text { longings }_{i, t-1}+\alpha \text { Controls }_{i, t-1}+\varepsilon_{t}
$$

To test hypothesis 2, that is, short-term fund shareholding has a significant negative impact on enterprise innovation, the following model (2) is constructed in this paper:

$$
\operatorname{rdint}_{i, t}=\beta_{0}+\beta_{1} \text { shortings }_{i, t-1}+\beta \text { Controls }_{i, t-1}+\mu_{t}
$$

where, rdint is innovation input expressed by R\&D expenditure/operating income; Longings and shortings are explanatory variables, respectively representing the long-term fund shareholding ratio and the short-term fund shareholding ratio. Control is the Control variable, including the natural logarithm of total assets, total asset growth rate, asset-liability ratio, current ratio, net interest rate on assets, receivables turnover rate, inventory turnover, growth rate of operating income, and the total shareholding ratio of top ten shareholders.

\subsection{Samples and Data}

This paper takes the listed companies in China's A-share market from 2006 to 2016 as a sample to analyze the impact of funds with different trading characteristics on the company's innovation investment. The fund shareholding data is calculated based on the shareholding details of all stock funds and hybrid funds in the wind database. The $\mathrm{R} \& \mathrm{D}$ investment and financial variables also come from the wind database. Whether the listed company is certified as a high-tech enterprise is derived from CSMR database.

This paper deals with the following data: 1) Excluding stocks classified as financial industry by the CSRC industry; 2) Excluding ST, ${ }^{\star}$ ST and delisting companies; 3) Excluding companies with incomplete financial information; 4) Excluding The missing value; 5) Is the range of variation of the control data, and the $1 \%$ and $99 \%$ quantile tailing processing of winsorize for all variables. 6) Excluding R\&D expenditure data, long-term shareholding, and non-observed data of short-term shareholdings during the sample period, excluding data with asset-liability ratio greater than 1 and operating income growth rate greater than 1.5 (eliminating the impact of mergers and acquisitions).

After the above data processing, 15,839 observed values were finally obtained.

Table 1 shows the types and meanings of the variables.

\section{Empirical Analysis}

\subsection{Descriptive Statistics and Correlation Test of Variables}

Table 2 reports descriptive statistics for the main variables. Among them, the 
Table 1. Variable definitions.

\begin{tabular}{|c|c|c|}
\hline Type & Vriable & Definition \\
\hline Explained variable & rdint & $\begin{array}{l}\text { represents the innovation input intensity, equal to } \mathrm{R} \& \mathrm{D} \\
\text { input/operating income }\end{array}$ \\
\hline \multirow{2}{*}{ Explanatory variable } & longings & $\begin{array}{c}\text { proportion of long-term fund shareholding in total } \\
\text { outstanding shares }\end{array}$ \\
\hline & shortings & $\begin{array}{l}\text { proportion of short-term fund shareholding in total } \\
\text { outstanding shares }\end{array}$ \\
\hline \multirow{9}{*}{ Control variable } & $\operatorname{lna}$ & natural log of total assets \\
\hline & gassets & total asset growth rate \\
\hline & gsales & operating income growth rate \\
\hline & lev & asset-liability ratio \\
\hline & current & current ratio \\
\hline & roa & asset net interest rate \\
\hline & $\mathrm{rt}$ & accounts receivable turnover \\
\hline & it & inventory turnover \\
\hline & sum 10 & total shareholding ratio of the top 10 shareholders \\
\hline
\end{tabular}

Table 2. Descriptive statistics for major variables.

\begin{tabular}{ccccccc}
\hline variable & $\mathrm{N}$ & $\mathrm{sd}$ & mean & $\mathrm{p} 50$ & $\min$ & $\max$ \\
\hline rdint & 15,839 & 0.0373 & 0.0368 & 0.0311 & 0.0002 & 0.2217 \\
shortings & 15,839 & 0.0805 & 0.0428 & 0.0031 & 0.0000 & 0.3995 \\
longings & 15,839 & 0.0084 & 0.0025 & 0.0000 & 0.0000 & 0.0538 \\
lna & 15,839 & 1.3733 & 12.3924 & 12.2796 & 9.5373 & 16.4989 \\
roa & 15,839 & 0.0706 & 0.0652 & 0.0526 & -0.1175 & 0.3157 \\
lev & 15,839 & 0.2014 & 0.4169 & 0.4136 & 0.0456 & 0.8574 \\
current & 15,839 & 0.0312 & 0.0241 & 0.0150 & 0.0000 & 0.2044 \\
rt & 15,839 & 0.5060 & 0.1895 & 0.0574 & 0.0095 & 3.8970 \\
it & 15,839 & 0.1300 & 0.0684 & 0.0381 & 0.0038 & 1.0816 \\
gsales & 15,839 & 0.2732 & 0.1669 & 0.1334 & -0.4204 & 1.1220 \\
gassets & 15,839 & 0.4359 & 0.2610 & 0.1338 & -0.2234 & 2.5814 \\
sum10 & 15,839 & 0.2520 & 0.5037 & 0.5629 & 0.0000 & 0.9096 \\
\hline
\end{tabular}

minimum value of $\mathrm{R} \& \mathrm{D}$ intensity is $0.02 \%$, the maximum value is $22.17 \%$, the average value is $3.68 \%$, the median value is $3.11 \%$, and the standard deviation is 0.0373, which indicates that China's listed companies generally have a low proportion of $\mathrm{R} \& \mathrm{D}$ investment and a large gap. The lowest and highest short-term fund holdings were 0 and $39.95 \%$, with an average value of $4.28 \%$, a median val- 
ue of $0.31 \%$, and a standard deviation of 0.805 . The minimum value of long-term fund shareholding is also 0 , and the highest value is only $5.38 \%$, with an average value of $3.10 \%$, a median value of 0 , and a standard deviation of 0.0084 . Obviously, not all listed companies will be favored by fund companies, and some of the company's shares are held by the fund. In the market, short-term funds have more total number, more shares and more participation than long-term funds. The natural logarithm of total assets represents the size of listed companies, with a standard deviation of 1.37, indicating that the size of companies varies greatly. The net interest rate on assets is negative at the lowest, $31.57 \%$ at the highest, with an average value of $6.52 \%$ and a median value of $5.26 \%$, indicating that some companies have financial losses in some years and most of them are profitable. The minimum asset-liability ratio is $4.56 \%$, and excluding insolvent companies, the maximum is $85.74 \%$. Accounts receivable turnover and inventory turnover show the company's turnover from different aspects. As for the growth of the company, the growth rate of operating income is $-42.04 \%$ and $112.20 \%$ respectively, with an average of 16.69. The lowest growth rate of total assets was $-22.34 \%$, the highest was $258.14 \%$, and the average was $26.10 \%$. The total shareholding ratio of the top 10 shareholders represents the concentration degree of the company's equity, with the highest value of $90.96 \%$ and the average value of $50.37 \%$.

Table 3 shows the correlation coefficient between the variables, most of the correlation coefficient between the variables is less than 0.1 , a small number of variables is slightly negative correlation, the correlation coefficient of all variables are all more than 0.6 given in this paper, using the panel data, multicollinearity effect on the estimated results can be ignored, and in this paper, the selection of control variable are based on the theory and a summary of a large number of previous studies, not random.

\subsection{Regression Result Analysis}

Table 4 reports the estimated results of the model. In order to eliminate the influence of sequence autocorrelation and heteroscedasticity, the robust standard error is used for all regression in this paper. After the regression of panel data using both fixed effect model and random effect model, Hausman test was used to test the setting of the equation of the model. All test results rejected the null hypothesis of the random effect model, so this paper finally used the fixed effect model and controlled the corresponding fixed effect of year and industry. The first column of the table shows that the regression coefficient of short-term fund shareholding on the $\mathrm{R} \& \mathrm{D}$ input intensity of enterprises is positive, but not significant, which is contrary to the expectation of this paper, indicating that the hypothesis is not established. The second column shows that long-term fund shareholding significantly promotes enterprise innovation, and the coefficient value is much higher than that of short-term fund shareholding. In order to explore the different impacts of fund ownership on enterprise innovation in enterprises of different industry natures, the third and fourth columns introduce the 
Table 3. Correlation test results.

\begin{tabular}{|c|c|c|c|c|c|c|c|}
\hline & rdint & shortfd & longfd & $\ln a$ & roa & lev & current \\
\hline shortfd & $\begin{array}{c}0.097 \\
(0.000)\end{array}$ & & & & & & \\
\hline longfd & $\begin{array}{l}-0.034 \\
(0.000)\end{array}$ & $\begin{array}{c}0.430 \\
(0.000)\end{array}$ & & & & & \\
\hline $\ln a$ & $\begin{array}{l}-0.253 \\
(0.000)\end{array}$ & $\begin{array}{c}0.074 \\
(0.000)\end{array}$ & $\begin{array}{c}0.166 \\
(0.000)\end{array}$ & & & & \\
\hline roa & $\begin{array}{c}0.130 \\
(0.000)\end{array}$ & $\begin{array}{c}0.132 \\
(0.000)\end{array}$ & $\begin{array}{c}0.110 \\
(0.000)\end{array}$ & $\begin{array}{l}-0.363 \\
(0.000)\end{array}$ & & & \\
\hline lev & $\begin{array}{l}-0.368 \\
(0.000)\end{array}$ & $\begin{array}{l}-0.131 \\
(0.000)\end{array}$ & $\begin{array}{l}-0.019 \\
(0.000)\end{array}$ & $\begin{array}{c}0.391 \\
(0.000)\end{array}$ & $\begin{array}{l}-0.300 \\
(0.000)\end{array}$ & & \\
\hline current & $\begin{array}{c}0.304 \\
(0.000)\end{array}$ & $\begin{array}{c}0.103 \\
(0.000)\end{array}$ & $\begin{array}{c}0.036 \\
(0.000)\end{array}$ & $\begin{array}{l}-0.237 \\
(0.000)\end{array}$ & $\begin{array}{c}0.187 \\
(0.000)\end{array}$ & $\begin{array}{l}-0.588 \\
(0.000)\end{array}$ & \\
\hline $\mathrm{rt}$ & $\begin{array}{l}-0.170 \\
(0.000)\end{array}$ & $\begin{array}{c}0.017 \\
(-0.031)\end{array}$ & $\begin{array}{c}0.071 \\
(0.000)\end{array}$ & $\begin{array}{c}0.160 \\
(0.000)\end{array}$ & $\begin{array}{c}0.022 \\
(-0.005)\end{array}$ & $\begin{array}{c}0.078 \\
(0.000)\end{array}$ & $\begin{array}{l}-0.067 \\
(0.000)\end{array}$ \\
\hline it & $\begin{array}{c}0.001 \\
(-0.897)\end{array}$ & $\begin{array}{c}0.025 \\
(-0.002)\end{array}$ & $\begin{array}{c}0.010 \\
(-0.199)\end{array}$ & $\begin{array}{c}0.049 \\
(0.000)\end{array}$ & $\begin{array}{c}0.051 \\
(0.000)\end{array}$ & $\begin{array}{c}-0.014 \\
(-0.073)\end{array}$ & $\begin{array}{c}0.020 \\
(-0.013)\end{array}$ \\
\hline gsales & $\begin{array}{c}0.033 \\
(0.000)\end{array}$ & $\begin{array}{c}0.162 \\
(0.000)\end{array}$ & $\begin{array}{c}0.069 \\
(0.000)\end{array}$ & $\begin{array}{l}-0.138 \\
(0.000)\end{array}$ & $\begin{array}{c}0.375 \\
(0.000)\end{array}$ & $\begin{array}{c}-0.003 \\
(-0.695)\end{array}$ & $\begin{array}{c}0.007 \\
(-0.412)\end{array}$ \\
\hline gassets & $\begin{array}{c}0.102 \\
(0.000)\end{array}$ & $\begin{array}{c}0.180 \\
(0.000)\end{array}$ & $\begin{array}{c}0.042 \\
(0.000)\end{array}$ & $\begin{array}{l}-0.127 \\
(0.000)\end{array}$ & $\begin{array}{c}0.299 \\
(0.000)\end{array}$ & $\begin{array}{l}-0.188 \\
(0.000)\end{array}$ & $\begin{array}{c}0.297 \\
(0.000)\end{array}$ \\
\hline sum10 & $\begin{array}{c}-0.026 \\
(-0.001)\end{array}$ & $\begin{array}{c}0.264 \\
(0.000)\end{array}$ & $\begin{array}{c}0.144 \\
(0.000)\end{array}$ & $\begin{array}{c}0.414 \\
(0.000)\end{array}$ & $\begin{array}{l}-0.327 \\
(0.000)\end{array}$ & $\begin{array}{l}-0.182 \\
(0.000)\end{array}$ & $\begin{array}{c}0.144 \\
(0.000)\end{array}$ \\
\hline & $\mathrm{rt}$ & it & gsales & gassets & & & \\
\hline it & $\begin{array}{c}0.078 \\
(0.000)\end{array}$ & & & & & & \\
\hline gsales & $\begin{array}{c}-0.005 \\
(-0.562)\end{array}$ & $\begin{array}{c}0.062 \\
(0.000)\end{array}$ & & & & & \\
\hline gassets & $\begin{array}{l}-0.048 \\
(0.000)\end{array}$ & $\begin{array}{c}0.023 \\
(-0.004)\end{array}$ & $\begin{array}{c}0.355 \\
(0.000)\end{array}$ & & & & \\
\hline sum10 & $\begin{array}{c}0.055 \\
(0.000)\end{array}$ & $\begin{array}{c}0.016 \\
(-0.041)\end{array}$ & $\begin{array}{l}-0.113 \\
(0.000)\end{array}$ & $\begin{array}{c}0.059 \\
(0.000)\end{array}$ & & & \\
\hline
\end{tabular}

Table 4. Regression results.

\begin{tabular}{ccccc}
\hline rdint & $(1)$ & $(2)$ & $(3)$ & $(4)$ \\
1_shortfd & 0.00508 & & $0.00864^{*}$ & \\
1_longfd & $(0.00335)$ & & & \\
& & $0.0754^{* *}$ & & $0.118^{\star *}$ \\
1_lna & -0.000191 & -0.000198 & -0.000423 & -0.000386 \\
1_gassets & $(0.00107)$ & $(0.00107)$ & $(0.00139)$ & $(0.00138)$ \\
& 0.000473 & 0.000536 & $-8.27 \mathrm{e}-05$ & $1.14 \mathrm{e}-05$ \\
1_gsales & $(0.000581)$ & $(0.000581)$ & $(0.000964)$ & $(0.000964)$ \\
& $-0.00394^{* * *}$ & $-0.00391^{* * *}$ & -0.00155 & -0.00154 \\
\hline
\end{tabular}




\section{Continued}

\begin{tabular}{|c|c|c|c|c|}
\hline & $(0.00101)$ & $(0.00100)$ & $(0.00147)$ & $(0.00146)$ \\
\hline \multirow[t]{2}{*}{ 1_roa } & -0.00978 & -0.00967 & -0.0163 & -0.0168 \\
\hline & $(0.00746)$ & $(0.00741)$ & $(0.0105)$ & $(0.0104)$ \\
\hline \multirow[t]{2}{*}{ 1_lev } & $-0.0109^{* * *}$ & $-0.0108^{* * *}$ & $-0.0161^{\star * *}$ & $-0.0162^{\star * *}$ \\
\hline & $(0.00307)$ & $(0.00307)$ & $(0.00505)$ & $(0.00504)$ \\
\hline \multirow[t]{2}{*}{ 1_current } & $0.0576^{* * *}$ & $0.0576^{* * *}$ & 0.0263 & 0.0251 \\
\hline & $(0.0169)$ & $(0.0170)$ & $(0.0229)$ & $(0.0228)$ \\
\hline \multirow[t]{2}{*}{ 1_rt } & $-2.36 \mathrm{e}-05$ & $-6.77 e-05$ & -0.000304 & -0.000385 \\
\hline & $(0.000772)$ & $(0.000773)$ & $(0.000914)$ & $(0.000915)$ \\
\hline \multirow[t]{2}{*}{ 1_it } & -0.00289 & -0.00277 & 0.00277 & 0.00286 \\
\hline & $(0.00661)$ & $(0.00660)$ & $(0.00551)$ & $(0.00553)$ \\
\hline \multirow[t]{2}{*}{ 1_sum10 } & $-0.00538^{\star \star \star}$ & $-0.00519^{* * *}$ & $-0.00528^{\star \star}$ & $-0.00510^{\star *}$ \\
\hline & $(0.00153)$ & $(0.00149)$ & $(0.00227)$ & $(0.00223)$ \\
\hline \multirow{2}{*}{ Hl_shortfd } & & & -0.00625 & \\
\hline & & & $(0.00661)$ & \\
\hline \multirow[t]{2}{*}{ Hl_longfd } & & & & -0.0752 \\
\hline & & & & $(0.0653)$ \\
\hline \multirow[t]{2}{*}{ Hl_lna } & & & 0.000533 & 0.000450 \\
\hline & & & $(0.00138)$ & $(0.00140)$ \\
\hline \multirow[t]{2}{*}{ Hl_gassets } & & & 0.00106 & 0.000999 \\
\hline & & & $(0.00112)$ & $(0.00112)$ \\
\hline \multirow[t]{2}{*}{ Hl_gsales } & & & $-0.00451^{\star \star}$ & $-0.00450^{\star *}$ \\
\hline & & & $(0.00191)$ & $(0.00189)$ \\
\hline \multirow[t]{2}{*}{ Hl_roa } & & & 0.0122 & 0.0130 \\
\hline & & & $(0.0148)$ & $(0.0147)$ \\
\hline \multirow[t]{2}{*}{ Hl_lev } & & & 0.00983 & 0.00998 \\
\hline & & & $(0.00609)$ & $(0.00609)$ \\
\hline \multirow[t]{2}{*}{ Hl_current } & & & $0.0513^{*}$ & $0.0533^{*}$ \\
\hline & & & $(0.0283)$ & $(0.0283)$ \\
\hline \multirow[t]{2}{*}{ Hl_rt } & & & 0.000564 & 0.000642 \\
\hline & & & $(0.00156)$ & $(0.00157)$ \\
\hline \multirow[t]{2}{*}{ Hl_it } & & & -0.0109 & -0.0110 \\
\hline & & & $(0.0122)$ & $(0.0122)$ \\
\hline \multirow[t]{2}{*}{ Hl_sum10 } & & & -0.000114 & -0.000157 \\
\hline & & & $(0.00306)$ & $(0.00299)$ \\
\hline Year fixed effect & controlled & controlled & controlled & controlled \\
\hline Industry fixed effect & controlled & controlled & - & - \\
\hline Constant & $0.0319^{* * *}$ & $0.0320^{\star * *}$ & $0.0315^{* * *}$ & $0.0316^{* * *}$ \\
\hline
\end{tabular}


dummy variables of high-tech enterprises into the equation. When the enterprise is certified as a high-tech enterprise, the value is 1 , otherwise it is 0 . The results show that short-term fund ownership can significantly promote the increase of innovation input of ordinary enterprises, but the promotion effect is reduced in high-tech enterprises, but the reduction effect is not significant; Long-term fund ownership can significantly promote the innovation input of ordinary enterprises. Similarly, this promotion effect is reduced in high-tech enterprises, but the reduction effect is not significant.

\subsection{Robustness}

In order to test the robustness of the estimation results, the ordinary least square method was first used for regression of the model. The results showing in Table 5

Table 5. Ols regression.

\begin{tabular}{|c|c|c|}
\hline rdint & (1) & (2) \\
\hline \multirow[t]{2}{*}{ 1_shortings } & $0.0377^{\star * *}$ & \\
\hline & $(0.00593)$ & \\
\hline \multirow[t]{2}{*}{ 1_longings } & & $0.156^{\star * \star}$ \\
\hline & & $(0.0579)$ \\
\hline \multirow[t]{2}{*}{ 1_lna } & $-0.00319^{* * *}$ & $-0.00312^{* * *}$ \\
\hline & $(0.000553)$ & $(0.000569)$ \\
\hline \multirow[t]{2}{*}{ 1_gassets } & 0.000630 & 0.00119 \\
\hline & $(0.000781)$ & $(0.000781)$ \\
\hline \multirow[t]{2}{*}{ 1_gsales } & $0.00258^{*}$ & $0.00393^{* * *}$ \\
\hline & $(0.00136)$ & $(0.00139)$ \\
\hline \multirow[t]{2}{*}{ 1_roa } & $0.0153^{*}$ & $0.0188^{\star *}$ \\
\hline & $(0.00849)$ & $(0.00851)$ \\
\hline \multirow[t]{2}{*}{ 1_lev } & $-0.0215^{* * *}$ & $-0.0224^{* * *}$ \\
\hline & $(0.00364)$ & $(0.00368)$ \\
\hline \multirow[t]{2}{*}{ 1_current } & $0.230^{* * *}$ & $0.229^{* * *}$ \\
\hline & $(0.0315)$ & $(0.0318)$ \\
\hline \multirow[t]{2}{*}{ 1_rt } & $-0.00727^{\star * *}$ & $-0.00742^{* * *}$ \\
\hline & $(0.000824)$ & $(0.000828)$ \\
\hline \multirow[t]{2}{*}{ 1_it } & $-0.0118^{\star}$ & $-0.0118^{*}$ \\
\hline & $(0.00628)$ & $(0.00626)$ \\
\hline \multirow[t]{2}{*}{ 1_sum10 } & $-0.00938^{* * *}$ & $-0.00639^{* * *}$ \\
\hline & $(0.00239)$ & $(0.00226)$ \\
\hline \multirow[t]{2}{*}{ Constant } & $0.0465^{\star * *}$ & $0.0460^{* * *}$ \\
\hline & $(0.00679)$ & $(0.00697)$ \\
\hline Year fixed effect & controlled & controlled \\
\hline Industry fixed effect & controlled & controlled \\
\hline Observations & 13,328 & 13,328 \\
\hline R-squared & 0.361 & 0.356 \\
\hline
\end{tabular}


indicate that short-term fund shareholding can significantly promote the increase of enterprise R\&D investment, and long-term fund shareholding can also significantly promote enterprise innovation, but the promotion effect of long-term fund shareholding is far greater than that of short-term fund shareholding.

In order to further test the robustness of the research results in this paper and solve the potential endogenous selection problem (that is, the predictable innovation input of the enterprise itself attracts the investment of the fund with a longer average holding time, while the long-term fund shareholding relative to short-term fund shareholding promotes the innovation of the enterprise). This article set company that meet the following conditions at the same time as the fund holding company for a long time, and the value is 1 : fund proportion of the total is more than $1 \%$, the total stake aggregate shareholding percentage accounted for the top 10 shareholders of not less than 5\%, the proportion of long-term funds is more than short-term fund holdings, otherwise for short-term funds holding company, the value is 0 . The binary variables as explanatory variables, control variables remain the same, using the model, the treatment effect of two-step model regression, Table 6 reports the estimated results, the results show that compared with the short-term funds holding company, long-term fund shares of the company's shares to increase R\&D spending to the company by the average of 0.0263 units.

Table 6. Treat effect model.

\begin{tabular}{|c|c|c|c|}
\hline & (1) & (2) & (3) \\
\hline & rdint & d_ls & hazard \\
\hline \multirow[t]{2}{*}{ d_ls } & $0.0263^{\star * *}$ & & \\
\hline & $(0.00726)$ & & \\
\hline \multirow[t]{2}{*}{ 1_Wlna } & $-0.00444^{* * *}$ & $0.332^{* * *}$ & \\
\hline & $(0.000562)$ & $(0.0141)$ & \\
\hline \multirow[t]{2}{*}{ 1_Wgassets } & 0.000878 & 0.0425 & \\
\hline & $(0.000727)$ & $(0.0383)$ & \\
\hline \multirow[t]{2}{*}{ 1_Wgsales } & $0.00429^{* * *}$ & -0.0360 & \\
\hline & $(0.00120)$ & $(0.0624)$ & \\
\hline \multirow[t]{2}{*}{ 1_Wroa } & $0.0273^{* * *}$ & $-2.079^{* * *}$ & \\
\hline & $(0.00534)$ & $(0.285)$ & \\
\hline \multirow[t]{2}{*}{ 1_Wlev } & $-0.0182^{\star \star \star}$ & $-1.163^{\star * *}$ & \\
\hline & $(0.00257)$ & $(0.106)$ & \\
\hline \multirow[t]{2}{*}{ 1_Wcurrent } & $0.229^{* * *}$ & -0.332 & \\
\hline & $(0.0117)$ & $(0.571)$ & \\
\hline \multirow[t]{2}{*}{ 1_Wrt } & $-0.00690^{* * *}$ & $-0.101^{* * *}$ & \\
\hline & $(0.000582)$ & $(0.0301)$ & \\
\hline 1_Wit & $-0.0118^{\star \star \star}$ & -0.0105 & \\
\hline
\end{tabular}


Continued

\begin{tabular}{cccc}
\hline & $(0.00242)$ & $(0.115)$ & \\
1_Wsum10 & $-0.00416^{* * *}$ & $-0.151^{*}$ & \\
& $(0.00146)$ & $(0.0785)$ & $-0.0130^{* * *}$ \\
lambda & & & \\
Constant & $0.0559^{* * *}$ & $-4.606^{* * *}$ & \\
& $(0.00575)$ & $(0.157)$ & 13,328 \\
\hline
\end{tabular}

\section{Conclusion}

Based on China's A-share market data from 2006 to 2016, as well as the shareholding data published by stock funds and hybrid funds, this paper divides fund investors into long-term funds and short-term funds according to whether the fund's average position time is more than one year, to study the impact of different types of fund investors' shareholdings on corporate innovation activities. The empirical results are different from the short-sighted studies of previous studies; short-term fund does not inhibit the investment in research and development, and long-term fund ownership can significantly promote the innovation investment of the company. In high-tech enterprises, this kind of promotion effect is inhibited, but the inhibition effect is not obvious. In recent years, institutional investors represented by funds have flourished in China. Compared with individual investors, institutional investors have strong economic strength and scientific management methods. Therefore, both objective and subjective factors can affect the management decisions of enterprises and affect the innovation activities of enterprises. Long-term funds can often have patience. While waiting for the long-term value of the company to improve, short-term funds are more concerned about short-term gains. However, most of the current shareholding funds are short-term investors who have closed their positions for less than one year. In the critical period of China's economic transformation, innovation is of utmost importance to enterprises, and the government has continued to pay attention to the innovation of enterprises, and has successively introduced relevant policies. Therefore, to promote enterprise innovation, this paper has the following recommendations: First, the government should encourage the development of funds, promote the long-term participation of funds in the A-share market, and improve various trading systems; second, fund companies can initiate funds for more situations. The project will provide a more reasonable and balanced allocation of long-term and short-term assets, and look forward to long-term returns in the case of guaranteeing short-term returns of funds; third, the intensity of innovation input among Chinese enterprises shows a trend of high dispersion, and the innovation input of high-tech enterprises has now exceeded the optimal promotion point, the high-tech companies should improve their ability to con- 
vert R\&D investment into innovative output, improve internal control systems, and improve the management's scientific decision-making level, under the premise of maintaining the stability of the company's internal system, attracts the participation of long-term institutional investors and actively learns the excellent management experience of large fund companies; fourth, the government should strengthen the guidance and supervision of institutional investors represented by funds, so that they can give full play to the positive role of institutional investors.

\section{Conflicts of Interest}

The author declares no conflicts of interest regarding the publication of this paper.

\section{References}

[1] Li, W., Bai, Y.X., Wei, S.Q. and Yu, X. (2018) The Impact of Corporate Governance on Enterprise Technology Innovation-Based on the Perspective of Industrial Analysis. Fujian Forum (Humanities and Social Sciences Edition), No. 11, 49-58.

[2] Liu, W. and Cao, Y.Q. (2018) Institutional Investors Drive the Real Economy to “Depart from Reality". Finance and Trade, 39, 80-94.

[3] Graves, S.B. and Waddock, S.A. (1990) Institutional Ownership and Control: Implications for Long-Term Corporate Strategy. Executive, 4, 75-83.

[4] Borochin, P. and Yang, J. (2017) The Effects of Institutional Investor Objectives on Firm Valuation and Governance. Journal of Financial Economics, 126, 171-199. https://doi.org/10.1016/j.jfineco.2017.06.013

[5] Bushee, B. (2004) Identifying and Attracting the "Right" Investors: Evidence on the Behavior of Institutional Investors. Journal of Applied Corporate Finance, 16, 28-35.

[6] Yan, X. and Zhang, Z. (2009) Institutional Investors and Equity Returns: Are Short-Term Institutions Better Informed? Social Science Electronic Publishing, 22, 893-924. https://doi.org/10.1093/revfin/hhl046

[7] Aghion, P., Reenen, J.V. and Zingales, L. (2013) Innovation and Institutional Ownership. CEPR Discussion Papers, 103, 277-304.

[8] Francis, J. and Smith, A. (2004) Agency Costs and Innovation Some Empirical Evidence. Journal of Accounting and Economics, 19, 383-409. https://doi.org/10.1016/0165-4101(94)00389-M

[9] Eng, L.L. and Shackell, M. (2001) The Implications of Long-Term Performance Plans and Institutional Ownership for Firms' R\&D Investments. Journal of Accounting, Auditing and Finance, 16, 117-139.

[10] Stein, J.C. (1988) Takeover Threats and Managerial Myopia. Journal of Political Economy, 96, 61-80. https://doi.org/10.1086/261524

[11] Stein, J.C. (1989) Efficient Capital Markets, Inefficient Firms: A Model of Myopic Corporate Behavior. Quarterly Journal of Economics, 104, 655-669. https://doi.org/10.2307/2937861

[12] Asker, J., Farremensa, J. and Ljungqvist, A. (2014) Corporate Investment and Stock Market Listing: A Puzzle? Review of Financial Studies, 28, 342-390.

[13] Koh, P.S. (2007) Institutional Investor Type, Earnings Management and Benchmark Beaters. Journal of Accounting and Public Policy, 26, 267-299. 
https://doi.org/10.1016/j.jaccpubpol.2006.10.001

[14] Acharya, V.V. and Xu, Z. (2015) Financial Dependence and Innovation: The Case of Public versus Private Firms. Social Science Electronic Publishing, 124, 223-243.

[15] Hsu, P.H., Tian, X. and Xu, Y. (2014) Financial Development and Innovation: Cross-Country Evidence. Journal of Financial Economics, 112, 116-135. https://doi.org/10.1016/j.jfineco.2013.12.002

[16] Jiang, Y.H., Tang, J.C. and Yao, Z.H. (2014) Institutional Investor Heterogeneity and R\&D Investment of Listed Companies-Experience Research on High-Tech Enterprises from A-Share Market. Economic Survey, 31, 86-91.

[17] Hong, M., Zhang, T. and Wang, G.K. (2018) Heterogeneous Institutional Investors and Enterprise Technology Innovation-An Empirical Test Based on Institutional Investors with Different Term. China Science and Technology Forum, No. 5, 57-70.

[18] Ming, Y.X. and Liu, N. (2018) Institutional Shareholding and Enterprise R\&D Investment-Based on the Perspective of External Governance. Technology Economics, 37, 20-27.

[19] Feng, G.F., Liu, H., Feng, Z.Z. and Wen, J. (2017) Will Stock Liquidity Promote Technological Innovation in Chinese Enterprises? Financial Research, No. 3, 192-206.

[20] Zhong, Y.X., Lv, H.L. and Li, Y.L. (2017) Management Short-Sightedness, Accounting Conservatism and Enterprise Innovation Suppression. Nankai Management Review, 20, 163-177.

[21] Bo, X.H. and Wu, L.S. (2009) The Governance Effect of State-Owned Holding and Institutional Investors: A Perspective of Earnings Management. Economic Research, 44, 81-91+160.

[22] José-Miguel, G., Massa, M. and Matos, P. (2005) Shareholder Investment Horizons and the Market for Corporate Control. Journal of Financial Economics, 76, 135-165. https://doi.org/10.1016/j.jfineco.2004.10.002

[23] Liu, J.J. and $\mathrm{Xu}, \mathrm{H} . P .(2012)$ Institutional Investors: Long-Term Investors or Short-Term Opportunists? Financial Research, No. 9, 141-154. 